\title{
A bélmikrobiom, a metabolikus betegségek és a hypertonia kapcsolatának irodalmi áttekintése
}

\author{
Barna István dr. ${ }^{1}$ - Nyúl Dóra ${ }^{2}$ - Szentes Tamás dr. ${ }^{3}$ - Schwab Richárd dr. ${ }^{2}$ \\ ${ }^{1}$ Semmelweis Egyetem, Általános Orvostudományi Kar, I. Belgyógyászati Klinika, Budapest \\ ${ }^{2}$ DVS Kft., Budapest \\ ${ }^{3}$ ÁNTSZ Országos Tisztifőorvosi Hivatal, Budapest
}

\begin{abstract}
A bélflóra olyan, mint az ujjlenyomat: minden embernek egyedi összetételű, rá jellemző baktériumfajokból álló mikrobanépesség él a bélrendszerében, amit ma bélmikrobiomnak hívunk. A baktériumok változatosságának, sokszínúségének (diverzitásának) csökkenése szoros kapcsolatot mutat a funkcionális bélbetegségekkel, az elhízással, a 2-es típusú diabetesszel és a cardiovascularis betegségekkel, valamint sok autoimmun megbetegedéssel. A székletgenomikai teszt során a bélflórát alkotó fajok pontos identifikálása és filogenetikai azonosítása révén meghatározható a diverzitás változása, illetve azonosítható bizonyos bélbaktériumok túlnövekedése. Praehypertoniás, hypertoniás egyénekben a Firmicutes törzshöz tartozó baktériumok elszaporodása, míg a Bacteroidetes törzsek csökkenése gyakrabban volt kimutatható, mint normotonia esetén, mindemellett az egyes baktériumtörzsek fiziológiai aránya kevésbé volt kiegyenlített. Az első megfigyelések arra utalnak, hogy kapcsolat állhat fenn a magas vérnyomás és az intestinalis baktériumflóra egyensúlyának megbomlása között, mind állatkísérletekben, mind emberben észlelhető hypertonia esetén. A vizsgálatok eredményei azt is felvetik, hogy a bél mikrobiotájának étrenddel történő célzott befolyásolása a magas vérnyomás nem gyógyszeres kezelésének új innovatív módszere lehet.

Orv Hetil. 2018; 159(9): 346-351.
\end{abstract}

Kulcsszavak: mikrobiom, székletgenomika, hypertonia, metabolikus szindróma

\section{Review of the relation between gut microbiome, metabolic disease and hypertension}

Gut flora has personal characteristics for each individual, similar to the fingerprints, consisting of a special mixture of bacterial species living in the intestines, now referred to as the gut microbiome. There is a strong correlation between the loss of microbial diversity and the functional bowel disorders, obesity, type 2 diabetes and cardiovascular disease as well as many autoimmune disorders. With genetic testing of stool diversity of the gut microbiome and exact analysis of the species and phylogenetic classification of the gut flora, the changes of diversity can be identified and the overgrowth of some bacteria can be revealed. In cases with pre- and manifest hypertension, an overgrowth of species from the phylum Firmicutes has been reported along with the relative decline of the phylum Bacteroidetes as opposed with cases of normotension. At the same time, the physiological balance among bacterial families was lost. According to the first studies, there is a correlation between hypertension and the lost balance of the gut microflora, both in animal experiments and in the human clinical setting. This evidence also suggests that targeted dietary alteration of the gut microbiome can be a new innovative approach in the treatment of hypertension.

Keywords: microbiome, stool genomic test, hypertension, metabolic syndrome

Barna I, Nyúl D, Szentes T, Schwab R. [Review of the relation between gut microbiome, metabolic disease and hypertension]. Orv Hetil. 2018; 159(9): 346-351.

(Beérkezett: 2017. április 16.; elfogadva: 2017. november 29.) 


\section{Rövidítések}

$\mathrm{CRP}=$ C-reaktív protein; DNS = dezoxiribonukleinsav; $\mathrm{GPR}=$ glikoproteinreceptor; IgG = immunglobulin G; LPS = lipopoliszacharidok; $\mathrm{MDP}=$ muramil-dipeptid; $\mathrm{rRNS}=$ riboszomális ribonukleinsav; $\mathrm{SCFAs}=($ short-chain fatty acids $)$ rövid láncú zsírsavak; SGT = székletgenomikai teszt

A mikrobiom, az emberi szervezetben élő, dinamikusan változó baktériumok, vírusok, gombák összessége [1]. A mind ez idáig legjobban feltérképezett terület a bélben élő baktériumok sokasága, de egyrészt az itt élő gombák, archeák, illetve az egyéb lokalizációban lévők - pl. bőr, szájüreg, légutak, urogenitalis tractus stb. - is egyedi mintázattal rendelkeznek, melyek kapcsolata egymással, a bélmikrobiommal, illetve ezek kölcsönhatása a változó környezeti és életmódtényezőkre intenzív kutatás tárgya.

Egy felnőtt bélrendszerében változatos baktériumflóra él, amelynek tagjai részt vesznek az anyagcsere-folyamatokban, a szénhidrátok lebontásában [2], serkentik több ásványi anyag - kalcium, magnézium, vas - felszívódását, továbbá $\mathrm{B}$-vitaminokat, $\mathrm{K}$-vitamint és egyéb védőanyagokat termelnek a szervezet számára. A bélflóra olyan, mint az ujjlenyomat: minden ember bélrendszerében egyedi összetételű, rá jellemző baktériumtörzsekből álló mikrobanépesség, mikrobiom él [3]. A szimbiózisban élő több ezer baktériumcsaládnak több mint 100-szor több génje van, mint szervezetünk összes sejtjének [4]. $\mathrm{Az}$ anaerobok aránya 1000:1. Becslések szerint az emberi kalóriabevitel 10\%-a tulajdonítható a bakteriális zsíranyagcserének [5]. Ezek alapján az egyik legfontosabb vizsgálandó kérdés, hogy a tápanyagbevitel és -felhasználás anomáliái milyen mértékben köthetők a megváltozott mikrobiomhoz, illetve ez hogyan befolyásolható. Az mindenesetre valószínúsíthető, hogy ebben a humán emésztőenzimek, a felszívófelület épsége, illetve a bevitt tápanyagokon kívül a mikrobiom épsége is fontos szerepet játszik.

A mikrobiom összetételének heterogenitása miatt sem egyszerû ennek meghatározása, kvázi „normálértékek” definiálása. Vannak arra vonatkozó adatok, hogy a klaszszikusan egészségesebbnek tartott tápanyag-összetételú „teljes kiőrlésű” kenyerek hasznosulásában, illetve metabolikus hatásában nagy individuális különbségek lehetnek a mikrobiom állapotától, illetve összetételétől függően $[6,7]$.

\section{A kórossá váló mikrobiom szerepe az emberi szervezetben}

A szív- és érrendszeri betegségek kialakulásának okaként ismert gyulladásos jelenségek hátterében az elmúlt években előtérbe került a humán mikrobiom jelentősége [8$10]$.

A mikrobiomnak nemcsak a bélrendszer normális müködésében van meghatározó szerepe, hanem az immunés endokrin rendszerre is hat. A baktériumok diverzitásá- nak csökkenésével párhuzamosan kialakul a dysbiosis, amely szoros kapcsolatot mutat a funkcionális bélbetegségekkel, az elhízással, a diabetesszel és a cardiovascularis betegségekkel [8]. Ha a bélflórát alkotó baktériumok jótékony diverzitása károsodik, bizonyos törzsek elszaporodnak, az immunrendszer számára antigén triggert alakítanak ki, és ez másodlagosan a gyulladásos aktivitás mentén a bélbarrier károsodásához is vezet. A helytelen összetételü tartós étrend következtében az egészséges egyensúly felborul, ennek súlyos következménye lehet az elhízás, az inzulinrezisztencia, a cukorbetegség, növekedhet egyes daganatos betegségek kialakulásának kockázata [9].

A bélrendszer belső felszíne mintegy kétszázszor nagyobb, mint a test felszíne. A bél barrier károsodásakor olyan makromolekulák juthatnak a bélből a keringésbe, amelyek potenciálisan immunogének. A helyileg kialakuló gyulladás hasmenést, székrekedést, fájdalmat, fokozott gázképződést eredményez. Obesitas esetén csökken a mikrobiom sokfélesége, ezzel a külső környezettel szembeni védekezőképessége is. A mikrobiom annál hatékonyabb, minél változatosabb, ez azonban nemcsak ország-, családfüggő, hanem az egyénre mindig jellemzően módosuló változó. A kedvező bélbaktériumok és a káros bélbaktériumok érzékeny egyensúlyát elsődlegesen az elfogyasztott táplálékok határozzák meg. Ha a bélben lévő baktériumok bejutnak a szervezetbe, vagyis átjutnak a bélfalon, akkor szöveti károsodást, illetve immunválaszt provokál(hat)nak. Az immunrendszerünk szoros kapcsolatban áll a mikrobiommal.

\section{A mikrobiom vizsgálata}

A mikrobiom genomikai módszerekkel történő objektív vizsgálata segíthet azonosítani azon bélben lévő, immunogénné váló faktorokat, amelyek hozzájárulhatnak a személyre szabott kezelési stratégia megválasztásához ennek markáns része az életmód átalakítása is.

A speciális székletgenomikai teszt (SGT) a bélflórát alkotó törzsek és fajok pontos genetikai azonosítása révén meghatározza a diverzitás változását, illetve azonosítani tudja bizonyos bélbaktériumok túlnövekedését. Kimutatható, hogy felborult az egészséges egyensúly. Segít feltárni az elhízás okát, hogy a cukor-, illetve a zsíranyagcsere zavara áll-e az elhízás hátterében. A diagnózis alapján arra is javaslatot tehetünk, milyen életmód-változtatással lehet egészséges irányba terelni a kedvezőtlen változásokat. Az egyénre jellemző mikrobiom viszonylag állandó, időszakosan azonban változó (pl. antibiotikum).

A prokaryoták $16 \mathrm{~S}$ rRNS-génjének azonosítására ma már nagy teljesítményú ún. szekvenálóberendezések állnak rendelkezésre, melyekkel a bakteriális DNS-szekvenciák azonosíthatók. Egyszerre igen nagy számú bakteriális genom vizsgálható a speciális chipek segítségével, és lehetővé vált a mikrobák alcsoportjának kimutatása is. 


\section{A székletben található törzsek}

Normális összetétel esetén a Bacteroidetes és a Firmicutes család mutatható ki a legnagyobb arányban, és kisebb mértékben van jelen az Actinobacteria és a Proteobacteria. Ezek a baktériumok képesek rövid és hosszú távon alkalmazkodni az életmód-változtatáshoz $[10,11]$. Az anyai baktériumtörzs meghatározó jelentőségü, ami később, a születéskor az egyénre jellemző módon módosul [12]. A természetes módon született csecsemők bélflóráját, bél-mikroorganizmusát elemezve nagyobb arányban észleltek „normális megoszlást”, mint a császármütéttel világra segített újszülöttek körében. A legnagyobb számban a bifidobaktériumok, a legkisebb arányban a Clostridium difficile és az E. coli volt kimutatható [13].

\section{Acidobacteriumok törzse}

Viszonylag újonnan, 1991-ben azonosított törzsek, mint az első faj ebben a csoportban. Ezek a mikrobák inkább savas környezetben élnek - úgy gondoljuk, hogy viszonylag gyakori csoport, jelenleg azonban még keveset tudunk biokémiai és egyéb anyagcsere-tulajdonságairól.

\section{Actinobacteriumok törzse}

A szárazföldi és vízben élő baktériumok tagjai. Mind a legkisebb és a legnagyobb, leginkább összetett baktériumsejteket tartalmazó baktériumok megtalálhatók ebben a csoportban.

Az Actinobacteriumok között a Streptomyces az egyik legváltozatosabb nemzetség a bakteriális világban, több mint 500 faja ismert. Ezek a csoportok termelik a klinikailag releváns, természetben előforduló antibiotikumok közel kétharmadát. Néhány fajról ismert, hogy betegséget okoznak, így a Gardnerella vagy a Lactobacillus. A bifidobaktériumok közé tartozó Gardnerella típusos humán kórokozó, nőkben bakteriális hüvelygyulladást okoz. A Lactobacillus bifidust probiotikumként alkalmazzuk, kedvező egészségügyi hatása a patogén kórokozók kontrolljában jelentkezik.

A Bacteroidetes törzs tagjai megtalálhatók a talajban, a tengeri állatok és az ember bélflórájában. Állatkísérletek arra utalnak, hogy a Firmicutes/Bacteroidetes emelkedett aránya gyakran társul elhízáshoz, és ez az arány rendeződik a testsúlycsökkenés hatására. A Bacteroides vulgatus és stercoris normálisnál nagyobb mennyisége esetén megnövekszik a vastagbélrák kockázata. Kisebb vastagbéldaganat-kockázatot észleltek Lactobacillusok alkalmazásakor. Evidencián alapuló tanulmányok szerint a legjelentősebbek a Lactobacillus- és a bifidobaktériumtörzsek, valamint a növényi eredetű Saccharomyces boulardii, illetve e fajták törzseinek kombinációi. A kritériumok megállapítására világszerte kontrollos tanulmányok folynak.
A Firmicutes család a bélben élő leggyakoribb baktériumtörzs. Az emelkedett Firmicutes-arány mind állatokban, mind emberben túlsúllyal társul, és a testsúly csökkenésekor számuk is csökken. Számos alosztálya és alcsoportja ismert (Clostridiumok, Bacillusok).

\section{Bélbaktériumok és hypertonia}

A mikrobiom összetétele alapvetően a táplálkozástól függ, tehát metabolikus szindróma esetén meghatározó jelentőségü. A Firmicutes baktériumok elszaporodása és a Bacteroidetes törzsek csökkenése a túlsúlyos állatokban és emberekben egyaránt gyakran mutat szoros összefüggést. Hasonló összefüggés mutatható ki inzulinrezisztencia esetén.

Praehypertoniás, hypertoniás egyénekben a Prevotella és a Klebsiella gyakrabban volt kimutatható, mint normotonia esetén [10]. Érdekes adalék lehet a praehypertoniát övező szakmai vitákban, hogy a mikrobiomváltozás vajon jobb prediktora lesz-e a későbbi manifeszt hypertonia kialakulásának, és ez alapján megbízhatóbb javaslatokat lehet-e tenni egyrészt életmód-intervenciókra, másrészt alacsonyabb (de kóros) vérnyomásértékek esetén a korai gyógyszeres kezelésére. Ennek nyilvánvalóan nagy prevenciós értékű, népegészségügyi jelentősége lenne, de csak célzott, kettôs vak-, randomizált klinikai vizsgálatok keretében dönthető el.

Két hypertoniás patkánymodell és egy kis humán populáció székletmintáiból nyert bakteriális DNS-mintákból végeztek genomelemzést. A spontán hypertoniás patkányokban jelentősen kisebb volt a mikrobák menynyisége, és a változatosságuk (diverzifikációjuk) is, az egyes baktériumtörzsek aránya kevésbé volt kiegyenlített, a Firmicutes/Bacteroidetes arány növekedett. Ezeket az eltéréseket az acetát- és a butiráttermelő baktériumok számának a csökkenése kísérte. A hypertoniás egyénekben végzett vizsgálatok hasonló megoszlást mutattak, a kontrollszemélyekkel összehasonlítva kisebb volt a baktériumok össz-száma és különbözősége. Patkányban angiotenzin-II tartós infúzióját követően csökkent a baktériumflóra gazdagsága, és nőtt a Firmicutes/Bacteroidetes arány. Ennek a modellnek a keretében az orálisan adott minociklin hatásosságát is elemezték a bél baktériumflórájának helyreállításában. A minociklin a vérnyomás csökkentése mellett képes volt a hypertoniás patkányok dysbioticus mikrobiotájának egyensúlyát is helyreállítani, csökkentette a Firmicutes/Bacteroidetes arányt. A megfigyelések arra utalnak, hogy kapcsolat áll fenn a magas vérnyomás és az intestinalis baktériumflóra egyensúlyának megbomlása között, mind állatkísérletes körülmények között, mind emberben észlelhető hypertonia esetén. A vizsgálat eredményei azt is felvetik, hogy a bél mikrobiotájának étrenddel történő befolyásolása a magas vérnyomás nem gyógyszeres kezelésének innovatív módszere lehet [14].

A rövid láncú zsírsavak (SCFAs) által termelt bélflóra és a vérnyomás-szabályozás kapcsolatban áll a vese szen- 
zoros idegeivel [15]. A rövid láncú zsírsavak aktiválnak két G-fehérjéhez kapcsolt receptort - GPR4l (más néven szabad zsírsav, savreceptor-3) és GPR43 (úgy is ismert, mint a szabadzsírsav-receptor-2). A rövid láncú zsírsavak reninfelszabadulást okoznak, aminek révén emelkedik a vérnyomás. A két receptor alaphelyzetben egyensúlyi állapotban van.

\section{Életmódprogram-diagnosztika}

Állatkísérletben igazolták, hogy a baktériumok mennyiségét és megoszlását, diverzitását számos egyéb tényező mellett a fizikai aktivitás is módosítja [16].

Az egyes egyénekre ugyanazok a tápanyagok, ételek különbözően hatnak, ezért a különböző diéták (Atkins, paleo, vércsoport stb.) eredményessége is eltérő.

Biztosan kijelenthető, hogy a bélben lévő baktériumtömeg kóros irányú elváltozása megváltoztatható, megfordítható. Az egészséges egyensúly helyreállítható, bár nem könnyű, mert az egészségtelen összetételű bélflóra befolyásolja az étrend megválasztását is: a beteg olyan ételeket kíván, amelyek a káros baktériumokat táplálják.

A nagy zsír-, kevés rosttartalmú „nyugati” étrend elősegíti a bélben a Gram-negatív kórokozók elszaporodását, és ennek következtében megnő a bél lipopoliszacharidtartalma, mintegy endotoxaemiát okozva. Ez állatkísérletekben a testsúlyt növeli, és emelkedett vércukorértékkel, hyperinsulinaemiával jár [17, 18]. A hazai táplálkozási felmérések szerint a lakosság rostfogyasztása a javasolt mennyiségnek (25-30 gramm) a felét sem éri el. A rosthiányos táplálkozás számos betegség kialakulásában (elhízás, cukorbetegség, magas vérzsírszint, hypertonia, metabolikus szindróma) veszélyeztető tényezőként szerepelhet. A rostok olyan növényi alkotórészek, összetett szénhidrátok, melyek nem emésztődnek meg, nem szívódnak fel, érintetlen formában jutnak le a bél alsó szakaszába. Egy részüket a vastagbélben található baktériumok képesek lebontani, és ezáltal olyan savas közeget létrehozni a vastagbélben, amely gátolja a rothasztó baktériumok elszaporodását. Gátolják a keményítőbontó amiláz aktivitását, aminek eredményeként lassul a szénhidrátok felszívódása, csökken az inzulinigény, javul a szénhidrát-anyagcsere, csökken az étkezések utáni hirtelen vércukor-emelkedés, így a vércukorszint ingadozása is, amely csökkenti a szív-ér rendszeri szövődmények kialakulását.

A vízben oldódó élelmi rostok előnyösen befolyásolják a zsíranyagcserét is, megkötik az epesavak formájában ürített koleszterin egy részét, amely így nem szívódik fel újra - ily módon csökkentik a vér koleszterinszintjét. Vízben oldódó, növényi rost a pektin, a mézgák, a guargumi, néhány hemicellulóz, a laktulóz-A. A legfontosabb a pektin, amely a gyümölcsökben (alma, citrusfélék, a legtöbb friss és aszalt gyümölcs), a zöldség- és főzelékfélékben, a gabonafélék közül a zabkorpában, zabpehelyben található. A magas rosttartalmú gyümölcsök közé tartozik a ribizli, a szilva, a szőlő, a mogyoró, a dió, a körte, az eper, az alma. A vizben nem oldódó növényi rostok közé a cellulóz, a hemicellulóz, a lignin tartozik. Cellulóz a zöldségfélékben (nagy rosttartalmú zöldségféle a zöldborsó, a karalábé, a cékla, a káposzta, és nagy rosttartalmú gabonaféle a búzakorpa, a bab és más hüvelyesek, a búzacsíra, a rozs, a szójaliszt, a kukorica), a teljes kiőrlésư lisztekben, a gyümölcsök héjanyagában és az olajos magvakban (mák, mandula, mogyoró) található. Hemicellulózt nagyobb mértékben a magvak külső héjanyaga, a fás szövetek, míg lignint a növények durvább, fás részei (például fás karalábé) tartalmaznak.

\section{A táplálásterápia lehetősége}

A mikrobiomkutatás egyik leginkább vitatott területe a táplálásterápia. „Általános” táplálkozási irányelvek megfogalmazása - a mikrobiom-összetétel nagyfokú heterogenitására tekintettel - nehézkesnek ígérkezik. A teljes kiőrlésű, illetve a fehér kenyér individuális glikémiás indexéről korábban idézett tanulmány [7] (a jogos kritikák ellenére) jól mutatja, hogy mennyire összetett a kérdés.

A biológiai rendszereknél megszokott módon úgy tünik, hogy komplex, többváltozós rendszerről van szó. Ennek központi eleme a bevitt táplálék minőségén és mennyiségén kívül a bélbarrier állapota, illetve maga a mikrobiom. Ezek egymást is befolyásolva olyan komplex biológiai rendszert képeznek, mely a szervezet környezeti terhelésével szorosan összefüggeni látszik (1. ábra). Máig nem pontosan tisztázott módon, de ennek a rendszernek a felborult egyensúlya az immunrendszer komplex aktiválódásához vezethet, ami a ma még a szakirodalomban nem pontosan definiált „áteresztóbél-szindrómához" vezet. Ezt összefüggésbe hozzák azzal az alacsony aktivitású, de a CRP-értékkel mégis mérhetó szisztémás gyulladásos állapottal is, mely a cardiovascularis megbetegedések okozta halálozás régóta ismert klinikai prognosztikai markere.

A táplálkozás hatása a mikrobiom összetételére és diverzitására is jól dokumentált. Meglepő módon arra is vannak adatok, hogy a mikrobiom önmaga befolyásolni képes azt, hogy a gazdaszervezet milyen ételeket, tápanyagokat „kíván”. Ez evolúcióbiológiai szempontból tulajdonképpen nem meglepő: a soksejtű, illetve egysejtű organizmusok kommenzalizmusán alapuló „ökoszisztémában", mint amilyen az emberi szervezet is, logikus, hogy azok a baktériumok, amelyek nagy befolyással bírnak a felszívódási folyamatokra, illetve a gazdaszervezet vitamin- és energia-háztartására, befolyásolni tudják (egyelőre nem tisztázott) neurohormonális mechanizmusokkal, hogy az mit fogyasszon el. A bélbarrier jelentősége itt elsősorban nem a tápanyagfelvétel, inkább azoknak a makromolekuláknak a „beáramlása” a szövetközi térbe, illetve a véráramba, melyek utána aktiválni képesek az immunrendszert, gyulladást okozva.

A hypertoniabetegség szempontjából kiemelt jelentősége van a veleszületett immunrendszer, illetve a bakteriális antigének, mint pl. a lipopoliszacharidok (LPS) és a 


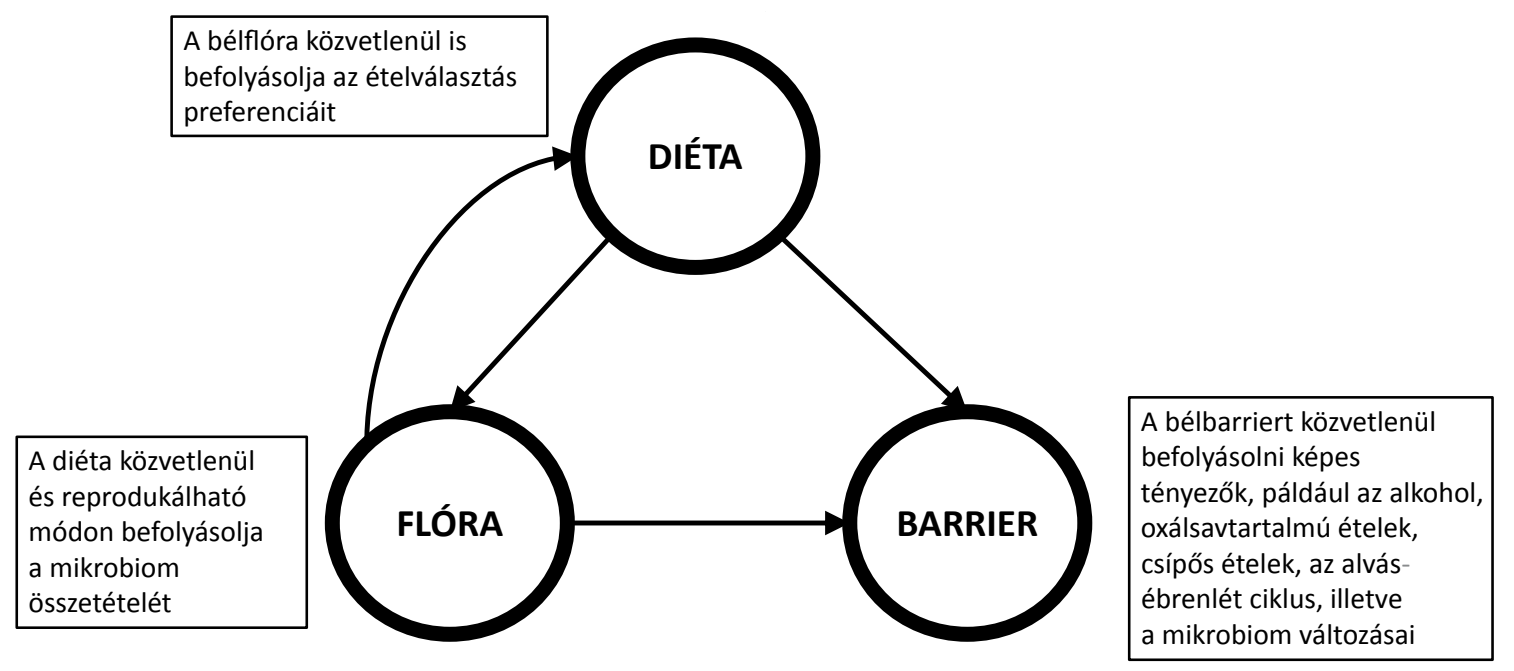

1. ábra

| A diéta, a mikrobiom és a bélbarrier komplex összefüggése

muramil-dipeptid (MDP)-molekulák interakciójának, melyek a Toll-like receptorok aktiválódása révén mediálódnak. A bélmikrobiom összetétele, illetve a bélbarrier épsége ezen keresztül közvetlen kiváltó tényezője lehet ennek a gyulladásos terhelésnek. A barrier állapotát ugyanakkor intrinszik veleszületett tényezőkön túl az étrend, a mozgás, a probiotikumok, az alkohol és a csípős ételek fogyasztása egyaránt befolyásolni képes. Az alvásébrenlét ciklus és a megfelelő minőségű alvás ennek ugyancsak fontos eleme.

A táplálásterápia számára ez nagyon széles spektrumú intervenciós lehetőségeket hordoz. Talán nem túlzás azt állítani, hogy a fenti mechanizmus kiindulópontja lehet a táplálkozás/életmód és a gyulladásos degeneratív megbetegedések kapcsolatának. Bonyolítja a klinikai ajánlásokat ugyanakkor, hogy a nagyüzemi mezőgazdaság által előállított élelmiszerek, ezen belül azok mikro- és nyomelemtartalma jelentős ingadozásokat mutat, illetve az elmúlt öt-hat évtizedben dokumentáltan jelentősen csökkent. Ez nyilvánvalóan komoly evolúciós nyomás alá helyezhette a beleinkben elő organizmusokat, és hozzájárulhatott a fejlett társadalmakban a bélmikrobiom-diverzitásban tapasztalt drámai csökkenéshez, a természeti népekkel összehasonlításban. Miután az élelmiszer-minősítési rendszerekből pont ez a mikro- és nyomelemösszetétel hiányzik, önmagában a fehérje-, szénhidrát- és zsírtartalom meghatározása szinte biztosan nem elégséges. A megfelelő mikro- és nyomelemtartalmú élelmiszerek előállítása, költsége és elérhetősége azonban nincs megoldva. Prospektív klinikai vizsgálatok feladata lesz meghatározni, hogy ezeknek a mikrobiomdiverzitás csökkenésében mekkora szerepük van, az antibiotikumok és egyéb környezeti és életmódártalmak mellett. Ugyanilyen fontos lenne tudni, hogy ezek a diverzitássérülések mennyire fordíthatók vissza. Abból kiindulva, hogy gyermekkorban a megfelelő minőségü anyatejes, majd hozzátáplálás, spontán kialakítja, fontos vizsgálni majd, hogy ez a célzott táplálásterápia a már kialakult, majd lepusztult mikrobiom helyreállítására is képes-e, vagy egyéb biotechnológiai intervenciót igényel majd.

Ismert, dokumentált a mikrobiomdiverzitás csökkenésének káros hatása a bélbarrierre. Ebből a szempontból érdekes adat, hogy ezt egyes probiotikus készítmények vissza tudják fordítani. Prospektív klinikai vizsgálatok feladata lesz meghatározni, hogy a magasvérnyomás-betegség kezelésének ez része lehet-e - az ezzel kapcsolatos ismeretek szórványosak és nem megfelelően dokumentáltak. Mindazonáltal a dysbioticus, túlnövekedett flóra visszaszorítása kvázi metabolikus kompetíció révén megvalósulhat. A veleszületett immunitást nagy fokban aktiválni képes antigénszerkezetû baktériumok kiszorítása olyan jótékony flórával, melyeknek a klinikai tapasztalat szerint ilyen aktiváló hatásuk nincs, mindenesetre magyarázhatja, hogy a jelenleg forgalomban lévő probiotikum hogyan tudja a barrierfunkciót helyreállítani [19].

\section{Következtetés}

A mikrobiom ismeretében az általános irányelvek könynyen megfogalmazhatók, személyre szabott tanácsadás azonban csak a mikrobiom ismeretében javasolt.

A magas vérnyomás nem homogén betegség, a diétás kezelés minden kezelés alapja. Megfelelő diétás ismeretekkel a lakosság több mint harmadát érintő állapot megelőzésében és kezelésében meghatározó jelentőségü az egyén mikrobiomjának ismerete.

A hypertonia kezelésére csak hazánkban több mint 50-féle gyógyszercsoportot, 800 gyógyszert, illetve kombinációt alkalmazunk, az egyes gyógyszerek azonban a hypertonia kialakulásának oki tényezőitől fogva más-más hatékonysággal alkalmazhatók. Egyértelmü, hogy a magas vérnyomásos betegek számára nem létezik általános „legjobb terápia”, amely az összes betegnél alkalmazható, s ugyanígy érvényes ez a diétákra is. A keze- 
lést a magas vérnyomás oka, a társbetegségek, a célszervkárosodás(ok) alapján kell végiggondolni, és ezután kerülhet sor a személyre szabott optimális terápia kialakítására.

Anyagi támogatás: A közlemény megírása anyagi támogatásban nem részesült.

Szerzôi munkamegosztás: A kézirat megírásában és az irodalom összeállításában minden szerző részt vett. A cikk végleges változatát valamennyi szerző elolvasta, jóváhagyta.

Érdekeltségek: A szerzők alapítói a Diavitas életmódprogramnak (www.diavitas.com), de a közlemény megírásáért, illetve az ezzel kapcsolatos tudományos munkáért semmiféle javadalmazásban nem részesültek.

\section{Irodalom}

[1] The Human Microbiome Project Consortium. Structure, function and diversity of the healthy human microbiome. Nature 2012; 486: 207-214.

[2] Brandi L, Cantarel BL, Lombard V, et al. Complex carbohydrate utilization by the healthy human microbiome. PLoS ONE 2012; 7: e28742.

[3] Arumugam M, Raes J, Pelletier E, et al. Enterotypes of the human gut microbiome. Nature 2011; 473: 174-180.

[4] Qin J, Li R, Raes J, et al. A human gut microbial gene catalog established by metagenomic sequencing. Nature 2010; 464: $59-65$.

[5] D'Argenio V, Salvatore F. The role of the gut microbiome in the healthy adult status. Clin Chim Acta 2015; 451: 97-102.

[6] Zeevi D, Korem T, Zmora N, et al. Personalized nutrition by prediction of glycemic responses. Cell 2015; 163: 1079-1094.
[7] Korem T, Zeevi D, Zmora N, et al. Bread affects clinical parameters and induces gut microbiome-associated personal glycemic responses. Cell Metab. 2017; 25: 1243-1253.e5.

[8] Eckburg PB, Bick EM, Bernstein CN, et al. Diversity of the human intestinal microbial flora. Science 2005; 308: 1635-1638.

[9] Festi D, Schiumerini R, Eusebi LH, et al. Gut microbiota and metabolic syndrome. World J Gastroenterol. 2014; 20: 1607916094.

[10] David LA, Maurice CF, Carmody RN, et al. Diet rapidly and reproducibly alters the human gut microbiome. Nature 2014; 505: $559-563$.

[11] Wu GD, Chen J, Hoffmann C, et al. Linking long-term dietary patterns with gut microbial enterotypes. Science 2011; 334: $105-108$.

[12] Wopereis H, Oozeer R, Knipping K, et al. The first thousand days - intestinal microbiology of early life: establishing a synbiosis. Pediatr Allergy Immunol. 2014; $5: 428-438$.

[13] Penders J, Thijs C, Vink C, et al. Factors influencing the composition of the intestinal microbiota in early infancy. Pediatrics 2006; 118: 511-521.

[14] Yang T, Santisteban MM, Rodriguez V, et al. Gut dysbiosis is linked to hypertension. Hypertension 2015; 65: 1331-1340.

[15] Pluznick J. A novel SCFA receptor, the microbiota, and blood pressure regulation. Gut Microbes 2014; 5: 202-207.

[16] Petriz BA, Castro AP, Almeida JA, et al. Exercise induction of gut microbiota modifications in obese, nonobese and hypertensive rats. BMC Genomics 2014; 15: 511.

[17] Cani PD, Amar J, Iglesias MA, et al: Metabolic endotoxemia initiates obesity and insulin resistance. Diabetes 2007; 56: 17611772 .

[18] Wright SD, Ramos RA, Tobias PS, et al. CD14, a receptor for complexes of lipopolysaccharide (LPS) and LPS binding protein. Science 1990; 249: 1431-1433.

[19] van Hemert S, Verwer J, Schütz B. Clinical studies evaluating effects of probiotics on parameters of intestinal barrier function. Adv Microbiol. 2013; 3: 212-221.

(Barna István dr.,

Budapest, Korányi S. u. 2/A, 1083 e-mail: istvan.barna@hypertension.hu)

\section{"Cunctis potest accidere quod cuivis potest." (Ami megeshet bárkivel, megeshet mindenkivel.)}

